\title{
The Commercial Banking Industry and its part in the emergence and consolidation of the Corporate Economy in Britain before 1940
}

\author{
Peter Wardley \\ University of the West of England, Bristol
}

'He did not think the banks had yet explored the enormous possibilities of mechanical methods. He thought the counter work at English banks was about as efficient as they could ever get, but he was suspicious as to whether they were as up to date behind the counter. He could see the banks of the future as possessing physical bodies of wonderfully contrived mechanism, almost everything of routine being done by machinery with the brains for the personal convenience of customers, and scientific conditions of control, a great civil service with a high tradition of public service, with opportunities for development and employment of many different talents. On the other hand, it was conceivable they might develop into mere money making machines.'

John Maynard Keynes, 'The future opportunities of the bank official'; presented at the Cambridge Centre of the Institute of Banking; reported in the Cambridge Daily News, I 5 October I927; and, reprinted as 'Mr J. M. Keynes on banking services' in the Journal of the Institute of Banking, November 1927, vol. xlviii, p. 497.

Banks engage in business which is intended to organise the profitable production of financial services and, like other privately-owned firms in a market economy, employ capital and labour to achieve this objective. Furthermore, as in other companies, it is within banks that more efficient combinations of capital and labour generate productivity growth. However, it has to be admitted that among banking historians, though usually not those who have written histories of banks, investigations of business structure, employment patterns, work organisation, labour relations and technological choice are notable usually for their omission. Nevertheless, these features of commercial banks, despite previous neglect, do have a wider significance for economists and economic historians and challenge a number of well-established historiographic prejudices.

Although banks are often treated as a special case, perhaps largely because their products are intangible, if not magical, to some observers, an investigation of bank organisation and performance can shed light on some often neglected aspects of modern economic growth. Three interrelated themes are highlighted here which suggest that the development of modern commercial banks can reveal significant but underappreciated facets of this vitally important phenomenon. These three themes, which are discussed in the context of British commercial banking before I939, recognise: first, the relative importance of the 
services in a modern economy, for which banking here stands as representative of that general class of activity; second, the functional significance of the financial sector and its relationship with other sectors of a modern economy; and, third, the consolidation of banks as large corporations which developed organisational structures adapted for the performance of banking activity in dynamic circumstances. While the third theme, which prompts questions about the consolidation, structure and organisation of the largest English commercial bands, receives the major attention here the other two themes are indicated to locate its proper context and insist upon its more general significance.

The contribution of service sector activity to the process of modern economic growth has only recently begun to receive attention from economists and economic historians commensurate with its relative contribution to economic activity. ${ }^{1}$ Typically it has been assumed that the industrial sector, and manufacturing in particular, has pride of place in the process of economic growth frequently, and significantly, referred to as the 'Industrial Revolution'. Nevertheless, the close association between sustained modern economic growth and the positive contribution of the services to productivity growth over the last century suggests that concentration on manufacturing leaves more than half the story untold, be it for an individual economy such as the United Kingdom, ${ }^{2}$ or for international comparative perspectives. ${ }^{3}$ Furthermore, the relationship between this process and the development of the large corporation, its key institutional determinant, alongside the state, suggests a complex and significant interconnection between the development of big business on the one hand and structural change and economic development on the other. 4

Second, and as indicated recently by Levine, 5 the significance and form of the financial sector for economic growth is a contentious issue: for some the financial system plays a crucial role, allowing the mobilization and direction of capital, whereas others regard its importance as either exaggerated or insignificant and barely worthy of mention. 6 One of the crucial tests for champions of the former proposition is the contrast between the British and German banking systems which are held to exemplify the market-based and the bank-based financial system respectively. It has been often suggested that in the late nineteenth and early twentieth century the German bank-based financial system generated more rapid industrial growth than the British market-based system. But a conclusive demonstration of this proposition has proved elusive and the conclusions of more recent investigations, which have drawn on detailed archival research indicate that the English banking system more closely resembled most other European systems than did the German. Moreover, the differences between these two systems appears much more striking in the pages of the banking manuals, and subsequent economic history textbooks, than it would have been to the bankers who operated in either systems. ${ }^{7}$ It also has to be admitted that the rhetoric of the bankers themselves, rather than their practice, may have contributed greatly to this comparative assessment.

The third theme is the emergence of complex, large-scale industrial corporations which collectively comprise the corporate economy, conventionally defined in terms of the activities of the modern business enterprise in the industrial and extractive sectors. ${ }^{8}$ This is another contentious issue and one where, yet again, the British example often does not escape unfavourable comparison. ${ }^{9}$ Chandler's most recent work suggests a taxonomy designed to illustrate international comparative analysis of the relationship between economic performance and the emergence of the modern industrial enterprise; 
this classifies the United States as 'competitive managerial capitalism', Germany as 'co-operative managerial capitalism, and the British system as 'personal capitalism'.10 For Britain, because of the persistence of personal capitalism, the consequences were deleterious as economies of scale or scope remained unexploited. Scale and Scope contains an oft-quoted paragraph which serves to crystallize the key elements of this managerial response which is taken to underpin the development of modern business enterprise and the Corporate Economy:

The first was an investment in production facilities large enough to exploit a technology's potential economies of scale or scope. The second was an investment in a national and international marketing and distributing network, so that the volume of sales might keep pace with the new volume of production. Finally, to benefit fully from these two kinds of investment the entrepreneurs also had to invest in management: they had to recruit and train managers not only to administer the enlarged facilities and increased personnel in both production and distribution, but also to monitor and co-ordinate those two basic functional activities and to plan and allocate resources for future production and distribution. It was this three-pronged investment in production, distribution, and management that brought the modern industrial enterprise into being. 11

These managerial responses are considered later, with specific reference to English commercial banking, but some general notes of caution should be identified immediately. On this side of the Atlantic, Chandler's verdict has been scrutinised with admiration but not a little scepticism because of the many facets of economic development which appear to have been banished from its ambit.12 Chandler has also not escaped criticism back in the U.S. A. ${ }^{13}$ Furthermore, a recent investigation of European big business by Cassis, which encompasses firms located in the United Kingdom, correctly emphasises the relatively large scale, longevity, profitability and overall success of large British companies. 14

Recent research has also demonstrated that at the beginning of the twentieth century, British firms, although frequently described as relatively small and managerially challenged, 15 were much larger than they have been portrayed. 16 The adoption of estimated market value as a standard comparator indicates that in 1905 , apart from a handful of major American corporations, the largest British and U.S. manufacturing companies fell within a very similar size range. Moreover, when this comparison is extended to all companies in both economies, so that service-providing companies are considered, rather than just industrial corporations, the much remarked upon difference in size between American and British companies disappears. 17 And English commercial banks figure prominently amongst these large service sector companies which are all too often overlooked in this context.

Concurrently, revisionist scrutiny has also been directed at the role of banks in the emergence of the British corporate economy, where they are customarily cast as neglectful and deficient suppliers of credit to industrial concerns. ${ }^{18}$ While bankers have often been blamed for restricting industry's access to capital in the interwar period, when they faced particularly severe criticism for creating a barrier to organisational change or rationalisation, ${ }^{19}$ a counterview suggests British banks were not systematically neglectful of industry's financial needs but the problems of the industrial sector were such they defied even the 
substantial resources, experience and clout of the English banks. ${ }^{20}$ Unsurprisingly, this unfolding academic debate reflects the divergence of opinion held by contemporaries. 21 Whereas critics of the banking system, mainly commentators and politicians, insisted that the British economy, and especially the industrial sector, was being handicapped by its banking system, bankers themselves, and not a few industrialists, forthrightly rejected this opinion, arguing that banks met fully their responsibilities to shareholders, customers and employees.

Two major aspects of interwar banking history are discussed below to emphasise their importance as key institutions in the emergence of the corporate economy in Britain. First, the emergence and consolidation of the large English commercial banks and their significance among the ranks of Britain's largest companies is outlined briefly. Attention then moves to the internal features of the major banks to consider their nature, structure and organisation. This second theme highlights the significant emergence of explicit managerial structures which divorced control from ownership, manifested an explicitly hierarchical bureaucratic system and accommodated strategic, functional and operational capabilities. These new managerial structures fostered the implementation of policies designed to achieve at least the following interconnected objectives: organisational change; increased functional specialisation; financial innovation; technical change; and, the consolidation of an internal labour market. Two explicit features of the latter were a formal career ladder and a discriminatory employment policy. Taken together, these objectives demonstrate the recognition and deliberate shaping of corporate culture. In short, British banks adopted a new business strategy in the I920s which both required significant managerial innovation and allocated the resources required to implement, supervise and control the achievement of that goal. Moreover, the determinants of this strategy were endogenous to the major British banks. Implementation of this new business strategy may have been timely, coinciding as it did with the onset of the Great Depression in Germany and the United States, but the economic difficulties which followed I929 were an exogenous factor which further justified existing policy rather than a primary spur to change.

The scale of the English commercial banks can be indicated by a number of measures, including: market value; employment; number of branch offices; assets; deposits taken; advances provided; and, profits, 22 both declared and actual. 23 The size of British commercial banks, as indicated by market value and their rank order among Britain's largest companies, is shown in Table $\mathrm{s} ;^{24}$ clearly, by 1905 Britain's largest banks qualified for inclusion among the ranks of international 'Big Business'. While consolidation of the United Kingdom banking system resulted in the primacy of the 'Big Five' by 1919,25 it also significantly increased concentration in the banking system; ${ }^{26}$ furthermore, as Table I shows, it also increased their relative standing in the national hierarchy of large companies.

The expansion of the Midland Bank, the largest of the 'Big Five', is demonstrated in Table 2 which highlights a number of significant features: the extent to which expansion had occurred before I9Io; the growth which took place in the decade dominated by the First World War; the further consolidation of the I920s; and, relative stasis in the decade before i940. For the Midland Bank it is also significant not only that expansion after I 920 came from the opening of new offices, rather than from further amalgamation, but also that rationalisation occurred with the closure of over one hundred and fifty branches, 
Table I. English commercial banks as big business: Market value of equity (£m.) and rank order of the English commercial banks among the largest British companies listed in diminishing size, by market value, in 1934/5 and 1904/5

\begin{tabular}{|c|c|c|c|c|}
\hline & & & & \\
\hline & $£ m$. & Rank & $£ m$. & Rank \\
\hline Midland Bank & 58.2 & (II) & I I.6 & (30) \\
\hline Barclays Bank & 54 & $(13)$ & 9.I & $(38)$ \\
\hline Lloyds Bank & 43.8 & $(2 \mathrm{I})$ & I $4 . \mathrm{I}$ & $(26)$ \\
\hline Westminster Bank & 38.7 & $(23)$ & 7.8 & $(47)$ \\
\hline National Provincial Bank & 34.2 & $(26)$ & $\mathrm{I} 3 \cdot \mathrm{I}$ & $(27)$ \\
\hline London and County Banking company & & & 9.8 & $(36)$ \\
\hline Parr's Bank & & & $7 \cdot 1$ & $(50)$ \\
\hline Union of London \& Smiths Bank, & & & 8.5 & $(4 \mathrm{I})$ \\
\hline Bank of England & $53 \cdot 7$ & $(14)$ & $44 \cdot 5$ & ( II $)$ \\
\hline Bank of Ireland & [IFS] & & $9 \cdot 9$ & $(35)$ \\
\hline
\end{tabular}

Source: P. Wardley (r99I) 'The anatomy of big business: aspects of corporate development in the twentieth century', Business History, vol. 33, no. 2, pp. 268-296; Tables 2 and 3 .

Notes: The Westminster Bank, as it became in I923, was the result of many amalgamations which transformed the original London \& Westminster Bank founded in I834; these include two banks which appear above as independent banks in 1905: the London and County Bank (amalgamated in 1909) and Parr's Bank (1918). The Union of London and Smiths Bank was the third bank listed above in 1905 which was subsequently amalgamated; it became part of the National, Provincial \& Union Bank in I918, retitled in 1924 the National Provincial Bank.

The Bank of England, the central bank for the United Kingdom, was privately owned by its shareholders, as was the Bank of Ireland which became the central bank of the Irish Free State (IFS) founded in 1922.

largely where facilities were locally duplicated.27 Like all its rivals, the Midland Bank engaged in an extensive, and expensive, building programme which saw the construction of new branches and re-location to new head offices near the Bank of England.28

Although the Midland Bank was the largest of the 'Big Five',29 it was not untypical. Modest shifts in relative size apart, 30 the stability achieved by the 'Big Five' during the interwar years stands in marked contrast to the experience of, for example, the financial systems of Germany and the United States in the early i93os. Nevertheless, despite similarities, each of the 'Big Five' had its own individual corporate culture. For example, with reference to organisational structure, the Midland is usually presented as the most centralised and Barclays the least. ${ }^{31}$ However, this balance of centrifugal and centripetal tendencies was one of emphasis, or degree, and it would be all too easy to overstate differences between the banks. Strategy for each of the 'Big Five' banks was determined by senior executives at headquarters located in London. And, although greater or lesser latitude could be granted by executive officers to senior managers in the regions, there was relatively little difference in the central office functions undertaken at the respective headquarters of the 'Big Five'. This communality of practice with regard to managerial 
innovation was also enhanced by frequent and detailed exchange of information between senior bank officers; by contrast, little or nothing was revealed at such meetings about each bank's respective customers and their terms of business.

Table 2: Midland Bank expansion, I880-1960

I) Balance sheet reports of paid up capital, deposits, advances, bills and actual profits, £ millions:

\begin{tabular}{|c|c|c|c|c|c|}
\hline & Capital paid up & Deposits & Advances & Bills & Actual profits \\
\hline I880 & 0.3 & 2.0 & $\mathrm{I} \cdot 3$ & 0.6 & 0.06 \\
\hline 1890 & 0.6 & $5 \cdot 6$ & 3.5 & $\mathrm{I} .4$ & O.I 4 \\
\hline 1900 & 2.5 & 37.8 & I9.8 & 4.I & 0.58 \\
\hline I910 & 4.0 & $73 \cdot 4$ & $4 \mathrm{I} \cdot \mathrm{I}$ & 6.7 & 0.89 \\
\hline 1920 & 10.9 & 37 I. 8 & I 89.7 & $57 \cdot 7$ & 4.2 \\
\hline 1930 & $\mathrm{I} 4.2$ & 399.6 & 203.6 & 83.9 & $2 . \mathrm{I}$ \\
\hline I939 & $\mathrm{I} 5.2$ & 496 & $22 \mathrm{I}$ & n.a. & 2.8 \\
\hline 1950 & I 5.2 & 1,392 & 344 & n.a. & 2.7 \\
\hline I960 & 24.2 & 1,709 & 759 & n.a. & 8.3 \\
\hline
\end{tabular}

2) Staff employed, total number of branches and sub-branches open, and sources of change in stock of branches:

\begin{tabular}{|c|c|c|c|c|c|}
\hline \multirow[b]{3}{*}{ I 890} & \multirow{3}{*}{$\begin{array}{c}\text { Staff employed } \\
350\end{array}$} & \multirow{3}{*}{$\begin{array}{l}\text { Branches Eु } \\
\text { sub-branches } \\
\text { open }\end{array}$} & \multirow{2}{*}{\multicolumn{3}{|c|}{$\begin{array}{l}\text { Branches added Branches opened Branches closed } \\
\text { by amalgamation } \\
\text { (over previous decade) }\end{array}$}} \\
\hline & & & & & \\
\hline & & & 8 & I6 & - \\
\hline 1900 & $\mathrm{I}, 500$ & 3 I 4 & I 49 & I I I & 8 \\
\hline I9Io & $3,69 \mathrm{I}$ & 689 & 247 & 135 & 3 \\
\hline 1920 & го,697 & $\mathrm{I}, 497$ & $5 \mathrm{I} 7$ & 274 & 5 \\
\hline 1930 & 13,192 & 2,100 & - & $69 \mathrm{I}$ & 9I \\
\hline I940 & I 3,548 & $2,03 \mathrm{I}$ & -* & I $26^{*}$ & $60 *$ \\
\hline 1950 & I 5,648 & $2, \mathrm{I}$ I 8 & n.a. & n.a. & n.a. \\
\hline 1960 & $2 \mathrm{I}, 970$ & 2,273 & n.a. & n.a. & n.a. \\
\hline
\end{tabular}

Sources: W. F. Crick and J. E. Wadsworth, A Hundred Years of Joint Stock Banking (I958: 3rd. ed.: Hodder and Stoughton: London), pp. 326, 333, 347; A. R Holmes and E. Green, Midland: 150 years of banking (I986: Batsford: London), pp. 323-326, 332-335, 339.

Notes: * Data only available for the quinquennium i $930-34$.

n.a. not available.

Here the managerial innovations and changes in accounting practices required to achieve bank amalgamation should not be underestimated, and neither should the contending sectional identities which evidenced a previous heritage. Naturally, the ensuing difficulties were probably most severe in a former head office rendered by amalgamation a mere branch. Even in the Midland, this process of internal consolidation was only completed a decade after the death, in I9I9, of its architect, Sir Edward Holden. 32 
The corporate culture of each of the 'Big Five' was a result of the varied history of the bank itself. Each constituent bank acquired during the long, drawn-out process of growth by amalgamation brought with it its own idiosyncratic practices and customs. As Crick and Wadsworth point out, this proved to be an enduring problem:

'Time and again amalgamations had given rise to the necessity of removing acute differences of method which involved inefficiency and waste. Often it was found that systems of branch organisation and control had been shaped on different lines, and it was necessary to bring these systems into uniformity in order to secure the highest common factor of efficiency.' 33

In the search for efficiency and internal uniformity each of the 'Big Five' banks introduced a number of managerial innovations; these included: the consolidation of managerial structures which permitted functional specialisation, both at the head office and in the individual branch; the development of internal labour markets; and, the introduction of new technology, which itself had major implications for the organisation, administration and operation of the major clearing banks. Many aspects of the labour process were transformed, with gender playing a significant role, such that the business culture of each of these organisations was reconstructed in the interwar period.

\section{Corporate development and the organisation of English banks before I939.}

Consolidation of the 'Big Five' required the development of clear management structures and a division of responsibilities between the head office and the branches. Much of this depended upon the transmission of high quality and relevant information: head office functions could be performed efficiently only if branches provided regular communication of appropriate standardized information; branches could act effectively only if the instructions issued from head office were regular, specific, and informed. New procedures were adopted, or old ones adapted, to ensure that the branch system worked under the supervision of the central office; it was, however, essential that these procedures, whatever their heritage, were formalised. Even where the necessary managerial structures were in place before the First World War, as in the case of the Midland Bank, ${ }^{34}$ they were reassessed and recast according to new demands, circumstances and opportunities. As discussed below, mechanization was an instance of this.

This essential divide between head office and branch resulted in formal functional specialisation which can be illustrated by a model derived from a contemporary account of English banking methods written by Leonard le Marchant Minty. 35 The term "model" is not used by Minty, but it does seem apt as he generalises to produce an archetype representing the essential organisational features of the 'Big Five', even though each had its own characteristics and idiosyncrasies. It is probable that the Westminster Bank was probably the closest to this ideal type. Figure I illustrates the departmental structure of a head office. The titles of the various departments refer to the various departments and indicate both their functions and the extent of internal functional specialisation. ${ }^{36}$ One department has been added to Minty's schema 37 - the Machinery Department, a very recent innovation, as demonstrated below. 
Figure I. Organizational structure, and functional specialisation by department, of the headquarter offices of an interwar British joint stock bank

Board Room:

Directors

Executive Offices:

Chairman

Managing Directors

Joint General Managers

Assistant General Managers

Functional departments:

Chief Accountant's Office

Branch Inspection Office

Chief Inspector's Office

Bill Office and Brokers' Loans

Stock Office

New Issues Office

The Coupon Office

Clearing Departments

Branch Ledger Department

Head Office Correspondence \& Circulating Department
Legal Department

Premises Department

Safe and Securities Department

Intelligence Department

Staff Department

Income Tax Department

Credit Information Department

Stationery Department

Machinery Department

Source: after L. le M. Minty (4th ed., London 1930) English Banking Methods.

Figure 2. Functional specialisation by department of a 'Foreign' or 'Overseas' branch of an interwar British joint stock bank

\section{Functional departments:}

Dealing Room

Telegraphic Transfer

Currency Account

Sterling Accounts

Cash or Clearing Department

Inland Payments

Commercial Credits "Inwards"

Commercial Credits "Outwards"

plus, specialist offices:

Enemy Debts Clearing Department

Cunard Office (Midland Bank)
Foreign Bills for Collection

Inland Bills

Securities

Mail Transfers

Correspondence Department

Source: after L. le M. Minty (4th ed., London 1930) English Banking Methods.

Even before the First World War, 'Big Five' banks had installed 'Foreign' or 'Overseas' departments to undertake banking business external to the United Kingdom: Lloyds Bank's foreign department was established in I898,38 the Midland's Foreign Banks Department by I902.39 True to their distinctive histories and corporate cultures, organisation of this facility varied by bank. Where the Midland Bank had a single centralised 
department, decentralisation determined that Barclays Bank's Chief Foreign Branch was supplemented not only by provision in the West End (Pall Mall, London) but also by Foreign branches in Manchester, Liverpool, Bradford, and in 1927, Birmingham.40 Like the Head Office, foreign branches or departments also exhibited specialisation by function: Figure 2 indicates the sections which provided the international banking services demanded by the customers of a 'Big Five' Bank.41 As a specific example of corporate enterprise, Minty highlighted here the Midland's establishment in I9I9 of a department to supervise its branch banks on board Cunard's ocean liners. 42 Specialist sections were also created to supervise transactions between branches overseas and branches in England and even to advise on 'Enemy Debts' after World War One. Interestingly, the foreign departments of a 'Big Five' bank often provided a initial testing ground for the implementation of new methods and techniques, including machine accounting. By the r92os, increasing demands on head office facilities and expansion of foreign business often required the relocation of the foreign branch to a separate but proximate location, increasing still further the necessity of a standardised managerial information system.

Although the determination of strategy and higher managerial functions were confined to the head office of a 'Big Five' bank, functional specialization was also to be found at the branches. By I930 an average branch probably had about seven staff but the larger branches could have circa thirty staff, including: a manager; a sub-manager; an accountant;

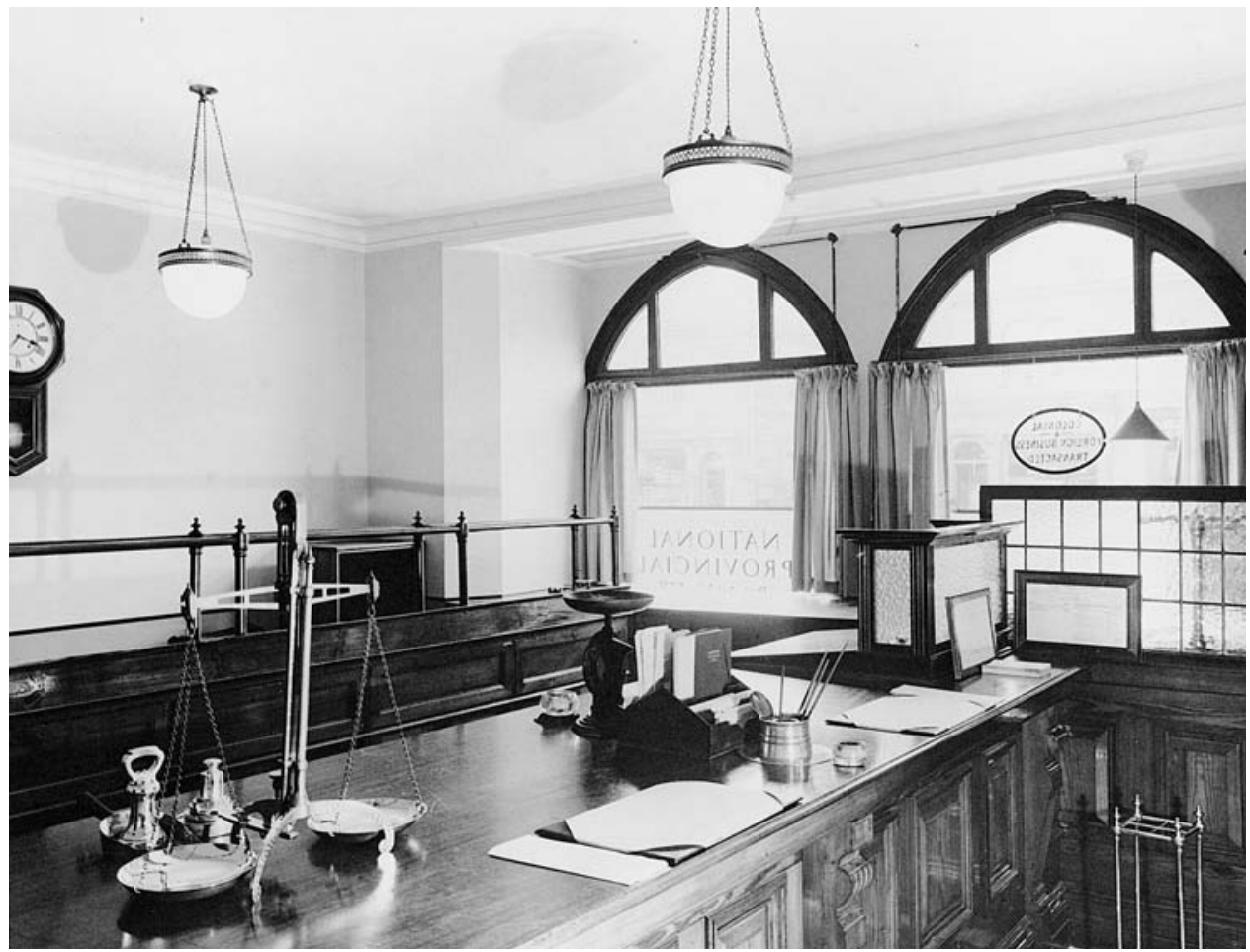

Figure 3. A traditional branch banking office - the Portishead branch of the National Provincial Bank at the beginning of the twentieth century. (NatWest Group Archives) 
four or five cashiers; four or five ledger keepers; between ten and twelve other clerks; two juniors; six lady clerks; two messengers and a nightwatchman. Here, too, the physical layout of the branch coincided with the functions delivered. The public were served by cashiers at the counter; behind was the waste office which accepted cheques and recorded the details in waste books; then came the ledger office where debits and credits were entered to customer accounts; and, last in this progression through the branch, was the Day Book, a department which processed information provided by the Ledger Officer and recorded it in Ledger Books and produced the all important trial balance. Additionally, there would be a Correspondence Office, a Bills and Securities Office, an Accountant's Office, where the returns to head office would be prepared, together with separate office accommodation for the Manager and Sub-Manager. ${ }^{43}$

It was the branch where most customers came into contact with the bank's staff. Only the most important clients had dealings with head office which scrutinised all major loans

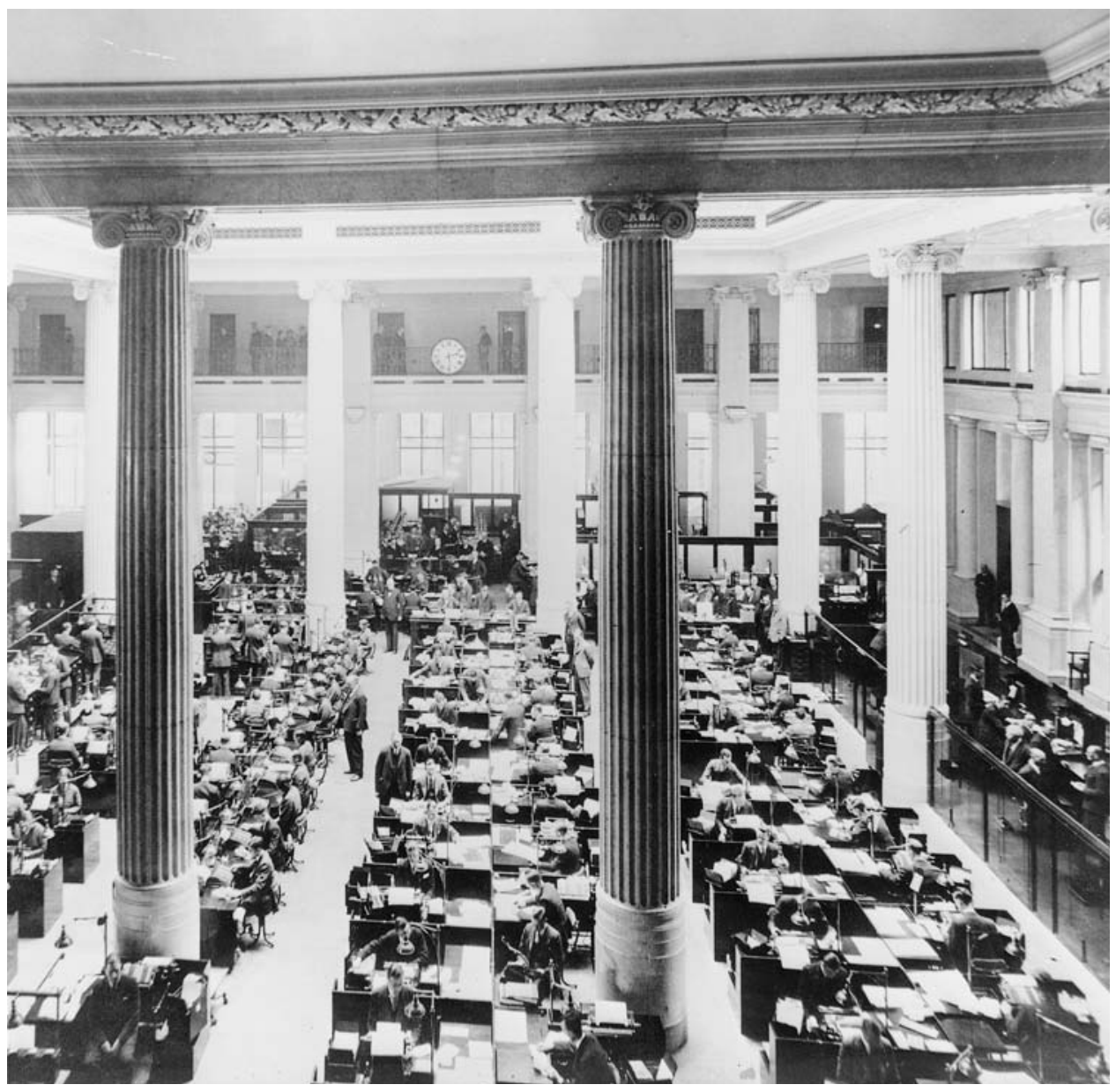

Figure 4. Machine banking in inter war Britain: the central banking hall at Lothbury after the mechanisation of the Westminster Bank's headquarter functions. (NatWest Group Archives) 
over a specified amount, below this stipulation a branch manager was allowed discretion. One important part of a branch's business was the search for new accounts and one financial innovation, the home safe, was introduced in the 1920 s to attract new customers with relatively small surpluses. Business undertaken in many branches also changed significantly as cheques became much more heavily used in the r920s and bills declined in relative importance. This shift in demand for bank services on the part of customers had major implications for the banks which faced a much heavier working load as a consequence and this was an additional stimulus to the search for cost cutting measures.

While the branches delivered the bank's services to its customers, the various departments functioned in accordance with the policies laid down by senior managers who, in conjunction with the board of directors, determined strategy. The functional intermediaries, who played the essential role of overseeing the communication and implementation of policy, were the Bank Inspectors. In addition to their role of 'policing' the branches to ensure accounting efficacy and probity, the inspectors ensured that policy and procedure was understood and acted upon by each branch. It was probably the Inspectors who initially saw the potential, and recognised the necessity of introducing new methods which would enable the bank to operate more efficiently. The Machinery Departments were closely linked and were eventually to be reabsorbed into the Inspection Departments. One important role usually played by the Inspection Department of a 'Big Five' bank was a regular review of the performance of individual staff members, this review informed decisions concerning promotion and salary increments which were essential features of the bank's internal labour market.

\section{Internal labour markets}

A substantial branch system directed by a centralized and specialist head office required a large number of employees and the development of internal labour markets; moreover, it required the development of a formal, standardised system to record the careers of all employees. 44 The 'Big Five' developed internal labour markets at least fifty years before economists drew attention to the consequences of this development. 45 In the context of a dual labour market, clearly the 'Big Five' provided 'primary' jobs designed to secure a stable labour force. Once admitted to a staff position through the limited 'port of entry', normally recruiting directly from school on the basis of examination performance, banks provided male staff with 'good' jobs: the rate of remuneration was relatively high; standard incremental pay scales offered protection against the vagaries of the market and arbitrary decisions of superiors; tenure was secure; pension rights were guaranteed; holidays entitlements and 'perks' were specified; and, for male entrants alone, a promotion ladder appeared to offer the opportunity to ascend to the summit of the managerial hierarchy. Furthermore, these contractual aspects were buttressed by a number of devices designed to foster a corporate culture; these included in-house staff magazines, social activities and sports clubs.

Trade unions often figure in the literature as important determinants of internal labour markets; however, although the banks tolerated or encouraged, perhaps less than enthusiastically the organisation of internal company-specific staff associations, the limited success of the Bank Officers Guild, which was registered as a trade union in I920, suggests this factor was marginal, if not irrelevant, in this case. Similarly, high labour 
turnover, another reason sometimes cited by labour economists to account for an internal labour market, can also be discounted. However, there was one determinant may have played a role here, though not one usually associated with the banking industry; internal labour markets are often associated with companies which are dynamic and exploit changing technology, which corresponds with the significance of mechanization ascribed below.

For banks, however, there was an obvious causal factor. It was particularly important for a bank to secure employees who exhibited specific personal qualities and characteristics including honesty, integrity and trust: theoretical issues associated with moral hazard and the principal-agent relationship are not difficult to identify in the banking industry. Moreover, not only were bank employees obliged to act so that they generated customer confidence when they appeared behind the bank counter or in the bank office they were also expected to act as respectable and trustworthy individuals outside working hours, playing a responsible role in the local society. 46

The 'Big Five' bank also developed discriminatory labour policies. By the r 930 female clerical staff also enjoyed tenure, incremental pay scales and, relative to other female workers, advantageous working conditions, but they received much lower rates of remuneration, 47 were subject to a marriage bar, 48 and faced a concrete rather than a glass ceiling, having no prospects for promotion to senior managerial or executive posts. Porters and messengers faced very restricted pay scales, sometimes age-related; however, gender discrimination continued even at this lower level in a bank's hierarchy as female cleaners and canteen workers received a lower, basic wage.

These internal market structures appear to illustrate an efficiency-orientated institutional response to the market forces generated by firm-specific jobs, training and technology as suggested by Williamson, Wachter, and Harris. 49 With the establishment of those parameters of the labour contract which could be explicitly specified to the satisfaction of both parties, given the realities of power relationships between management and employees, at least some of the costs of perpetual bargaining over the labour effort and turnover costs were reduced or eliminated.

Moreover, as the banks improved their screen processes, through the introduction of training courses, encouragement of examination success and, in particular, appraisal schemes, it became possible to encourage efficiency through the promotion of staff judged meritorious. Thus the effects of promotion, both effective and demonstrative, reduced the costs of monitoring and supervision and contributed to the development of an efficient internal labour market. Pay scales and promotion ladders not only encouraged staff to acquire the specific information and skills required to fulfil their current employment obligations but also ensured that staff had opportunities to develop specific training which would equip them to serve in senior posts (learning, at the very least, "sitting by Nellie"). Consequently, when acting in either a supervisory or policy-making capacity, managers would not only understand the nature of the job but they would also understand how and why it was done.

Although remuneration was paid to the job rather than on an assessment of individual performance, the 'Big Five' developed similar internal markets, each bank ensuring that training was a complement to the production of bank services and screening advancement for appropriate individuals according to specific criteria; such institutional relationships and arrangements, it has been suggested, 'may well be the most efficient apparatus for 
Figure 5. "Then" and "Now". C. Sporn's cartoon refelecting changing attitudes to women employees. NATPROBAN (Autumn 1938), p. 77 . (NatWest Group Archives)

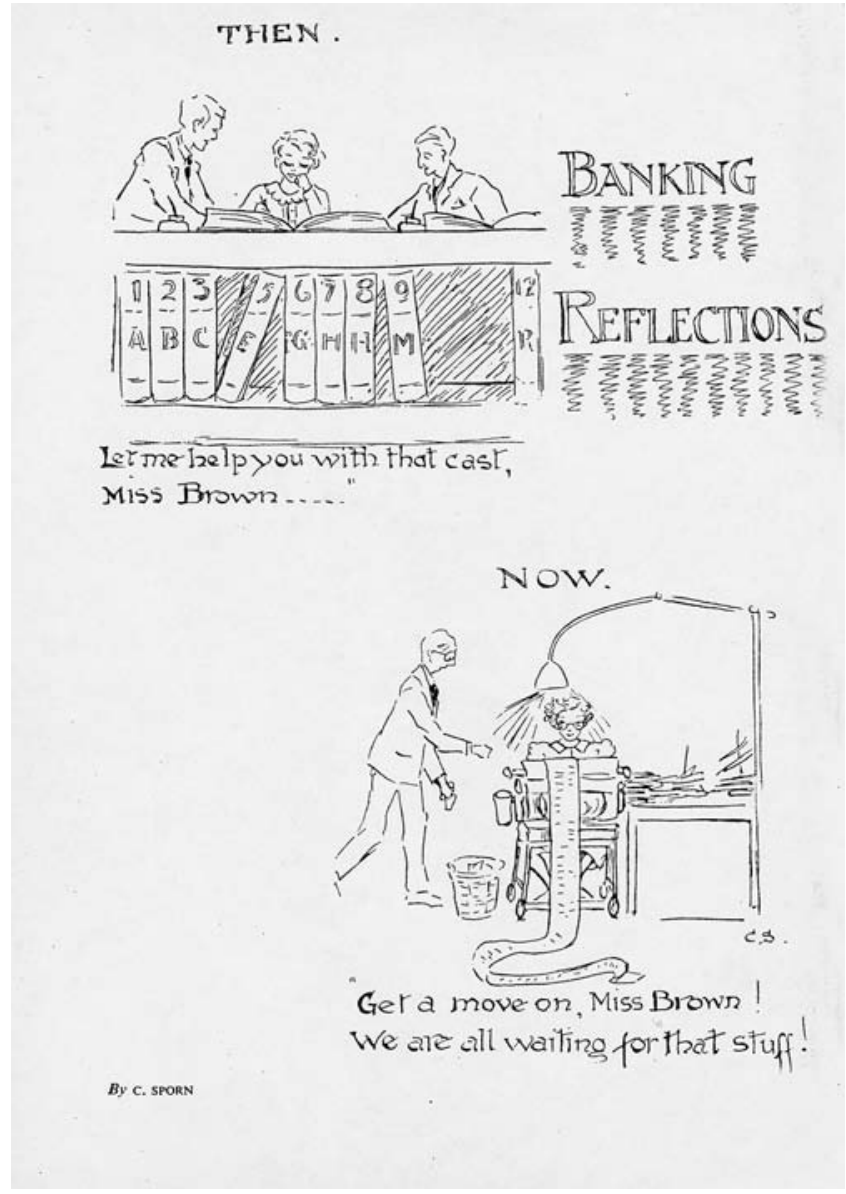

collecting and analysing data on individual performance'.50 Although some of these institutional relationships already had a long history by the outbreak of the First World War, many were relatively new, and probably the majority of these arrangements were disrupted by changes introduced in the I920s. After I 928 mechanization was to transform many aspects of bank practice.

\section{Mechanization, machine ledger keeping and centralization in English Commercial Banks}

Although the telephone could be seen as the pioneering modern technology, many new techniques and gadgets were adopted in commercial offices, banks included, at the beginning of the twentieth century. ${ }^{51}$ Alongside typewriters, besides steel filing cabinets, and under electric lighting, a range of new materials, products and techniques were to be found that supplemented novel adding machines introduced as the first mechanical aids to banking almost coincident with the outbreak of the First World War.

The major technical innovation of the interwar period introduced both at head offices 


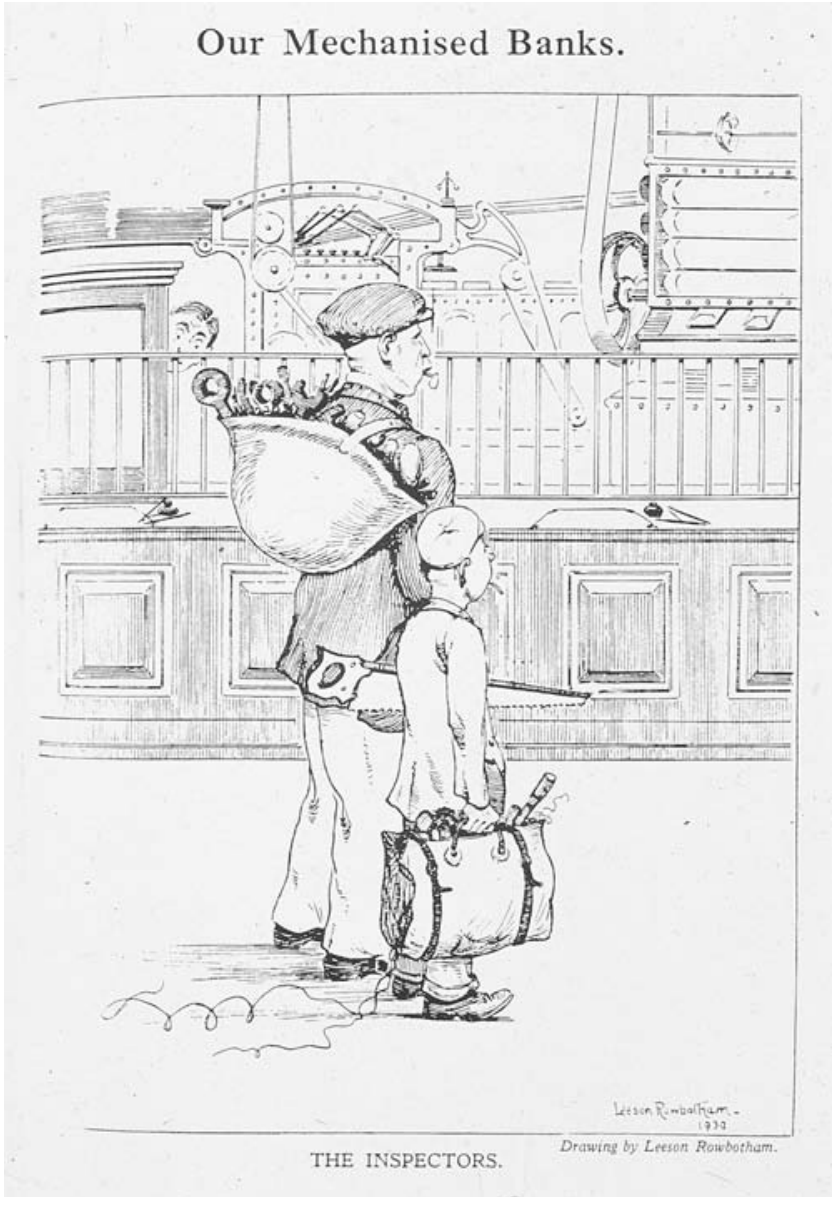

Figure 6. 'Our mechanised banks: the inspectors call', Spread Eagle (1930), p. 53 I. (Barclays Bank Archives)

and in the branches of the 'Big Five' was the introduction of accounting machines which allowed the posting, or data handling, of bank ledgers and customer statements, both commercial and personal. With accounting machines came standardization as their introduction transformed banking operations with the implementation of procedures designed to ensure all data handling (i.e. data collection, data presentation, data processing, data storage and data retrieval) were systematic and uniform. The specific machines preferred by an individual bank depended upon an assessment of the features supplied and the bank's requirements, but each of the 'Big Five' responded to rising costs and an increase in business, both the number of customers and transaction undertaken, by adopting this technology.

While this technology could be described as primitive and unwieldy from a vantage point at the end of the twentieth century, it was the "cutting-edge" technology of its day. Furthermore, in addition to being an essential step to technically superior systems, this technology, and the associated management information system created to utilise it, was a highly successful innovation provided the key-stone of the banks' operations for the next thirty years, when it was replaced by new management systems created to 


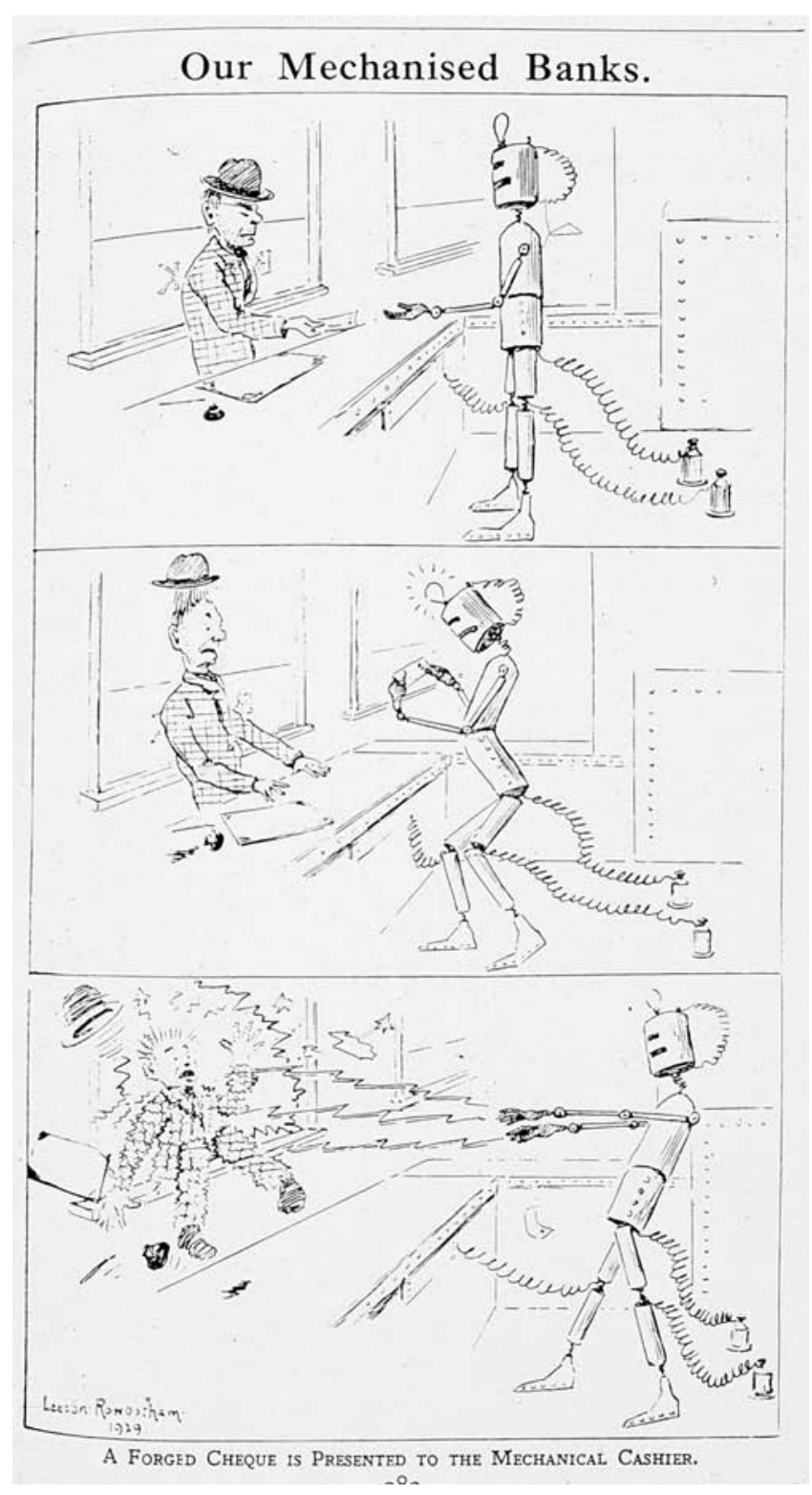

Figure 7. 'Our mechanised banks: a forged cheque is presented to the mechanical cashier', Spread Eagle (I93I), p. 283. (Barclays Bank Archives)

accommodate mainframe computers. For those who like to view the development of economies and businesses in terms equivalent to biological processes this sequence can be seen as an excellent example of punctuated equilibrium where a period of stasis is followed by one of rapid change after which stasis is restored, with the possibility of a similar epoch of transition disturbing the new equilibrium at a later date. 52

Detailed descriptions of the technology and assessments of the various machines appeared in the banking journals, particularly in the autumn of 1929 when this was a 'hot' topic. Full descriptions and technical details of neither the book-keeping systems 
nor the various machines is provided here, although the relevant manufacturers are indicated by reference to a contemporary expert, assessing a decade of machine banking in an article published in 1938, who would have sympathised with this omission:

"It will be noticed that I have made no attempt to distinguish between methods of book-keeping in the proposed centralized book-keeping offices. It does not seem to me important for the moment to discuss whether the machines of the Burroughs, National Cash Register, Remington etc. companies are used, nor is this the place to argue the merits of these machines as against entirely different methods such as are utilized by punched-card machines of the Hollerith or Powers-Samas type." 53

By the mid-r 920 senior managers of the 'Big Five' held growing concerns about rising costs of production and control over the process of production which gave rise to an interest in mechanization.54 Although the Midland Bank and the Westminster Bank were the most visible proselytisers, reporting their progress in a 'Special Issue' of The Banker (itself an unusual, if not unique, event) entitled 'Bank Mechanization' in August I929, the other large commercial banks were already inaugurated their own systems. By I930 the 'Big Five' had all introduced more or less complete systems of machine-book keeping and similar systems had been introduced at many of the London offices of the Colonial banks. However, although the systems were complete, implementation was largely restricted to Head Offices and larger branches. As implementation continued the minimum size of an economically viable machine ledger branch fell from the initial estimate of $\mathrm{I} 5$ staff in 1928 to $\mathrm{I}_{2}$ in $\mathrm{I} 930,55$ and to 8 in $1933 .{ }^{56}$ At this limit mechanization would have been economic in only about half the branches of each of the 'Big Five' but the scope for mechanization was enlarged by grouping smaller branches together in a local clearing pool served by a single mechanized branch which processed the records of the others.

Centralization, 57 as this was known at the Midland Bank, was implemented in December I 929 and discussed at a meeting of the Institute of Banking Debating Society the following month. The star performer was at this session was H. L. Rouse (Assistant Chief Accountant at the Midland Bank). Rouse reported the extent to which mechanization had been introduced, with 73 branches converted to the new system, and plans for a further 45 branches to be converted during I930. The new system already accommodated approximately i65,000 accounts and catered for 7,000,000 postings a month; in all 325 machines had been installed; 296 machines at Head Office and various large branches, plus 29 machines to cope with the work at months end and heavy periods. Rouse also reviewed branch expansion and the increase in employment in the Midland Bank since I924 to indicate how mechanization allowed the substitution of female labour and capital for male staff with a consequent reduction in cost. 58

Rouse also explained that although the proportion of women employed in the bank would increase, the promotion opportunities of newly recruited male clerks would improve and, from the bank's point of view, this would encourage the quality of male recruitment; the latter had been a recurrent cause for concern for the senior officers since mechanization had begun and it had only been made worse by the restraint on recruitment which followed the economic downturn after i 929. The allocation of mundane and repetitive tasks to female machine operatives would facilitate more rapid promotion of junior male staff 'to undertake such responsible tasks as the discounting of bills, cashiering, and 
security work'. He also pointed out that with this creation of two distinct categories of staff, with supervisory and clerical grades, British banks would more closely resemble Continental and American banks. 59

Mechanization in the 'Big Five' even had an impact on popular culture, as reports of robotic bankers swept the national press when a machine accounting system was introduced at Lothbury, the head offices of the Westminster Bank, on I 8 April I933. This was accomplished only after a full appraisal of the Bank's existing system and its functional departments (see Figures I and 2) had been conducted to plan a comprehensive re-organisation of management structures and operations. This strategic view informed the detailed specification of the plan and drew upon experience gained in the mechanization of over a hundred branches and Threadneedle Street. Mechanized in February 1932, Threadneedle Street was the location of some head office functions, including the bank's training school. Once the decision had been taken to mechanize Lothbury, accounting machines were selected, after careful appraisal of the range of available models, and intensive six week training programmes were organised at the Bank's training school, which equipped head office staff with the skills required to operate the system to be implemented. After the event, this training, which had been followed by an ensuing period of practical experience in a mechanized branch, was recognised as being of 'enormous importance'.60 Finally, the internal lay-out of Lothbury was reconstructed, section by section, to minimise disturbance to business (see Figure 4), according to plans drawn up the bank's architect to meet the following criteria:

'I. Every ledger and statement poster, and every control operator, has what is effect an office to himself including all the desk space and filing accommodation required for his work. He can, therefore, work in complete comfort, and no matter how much traffic there is in the gangways he cannot be incommoded.

2. All other machine operators have desks beside the machines of sufficient size for the work of sorting, etc., and ample gangways behind them so that they also can work in comfort.

3. All lighting has been specially designed so that any glare from the keys is avoided. The amount of light is ample and can be varied by each operator. There is a separate light for each machine.

4. Every machine has a separate fuse plug beside it with a cartridge fuse so that a fuse blowing affects only the particular machine and takes on a few seconds to replace.

5. Everything has been so arranged that the work flows forward from one stage to the next with the minimum amount of movement. Cross traffic has been avoided.

6. Very ample filing space of the most suitable design for the particular forms, etc., has been provided in the places most convenient for the work.' 61

Careful specification of working conditions was matched by a close inspection of work undertaken by head office departments. After a detailed study of departmental organisation at Lothbury, work was reorganized so that: all possible work was mechanized; all work in mechanized departments which could not be mechanized was transferred to non-mechanized departments; the procedures of non-mechanized sections were changed so they integrated with those of mechanized sections; and, 'everyone in non-mechanized 
sections understood exactly the changes, if any, that machine accountancy would necessitate in their existing procedures'.62

Within a year of its original conception, and after six months of careful preparation for its execution, the changeover from the hand-written system to machine accounting at the Westminster Bank was achieved between the close of business on Easter Saturday and the next working day. 63

Having illustrated the extent of managerial changes implemented in the 'Big Five' during the interwar period, there remains the question of its efficacy in producing cost reductions. The example of the Midland Bank will suffice, at least for the moment, to indicate the scale of economies achieved by mechanization, the associated influx of female staff and managerial reorganization in general. Six years after the initial implementation of mechanical ledger posting Rouse was able to refine his earlier estimate that two male clerks could be released for the cost of one female machine operator with more definite results: 'the actual figures show that for every two ledger-posting machines installed, 2.I male clerks have been released and it has only been necessary to engage . 5 female operators for every two ledger-posting machine installed'.64 As female salaries (circa $£_{\text {I }} 50$ p. a.) were half those of their male counterparts (circa $£_{300}$ p. a.) this represented a significant saving in labour costs. As the ledger-posting machines cost in the order of $£_{42}$ and had a life expectancy of about ten years, the total savings, after allowing for the cost of the capital equipment were far from insignificant. Contemporary estimates, based conservatively on Rouse's initial evaluation of staffing redeployment, suggested that the break-even point, after investment in all aspects of the system (i.e. including training, accommodation, sundry expenses etc.), would occur about two years after the installation of accounting machines. In crude terms, though, the saving achieved by the installation of each machine approximated to the salary of a male staff employee.

Overall, it would appear that by 1939, through the introduction of machine accounting the 'Big Five' had collectively made annual net savings on costs in excess of $£_{\text {I }}$ million; 65 this was a reduction equivalent to about $7 \%$ of total labour charges and circa $3 \%$ of total costs. Although all the savings achieved through related managerial and employment changes are not included in this estimate, it does represent an initial, though approximate and admittedly conservative, financial estimate of the economies of scale achieved by the 'Big Five' through the operation of national branch banking systems supervised centrally from a head office.

However, mechanisation of British banking accomplished much beyond its cost cutting objective. In addition to the direct economic benefits which accrued from the introduction of machine banking, the impact of the new technology was considerable and all-pervasive: the new machines had an obvious presence, which often required reconstruction of the office space needed to accommodate them; working them necessitated new work practices; and, their impact on social relations at work was significant and extensive. The extent of this influence, and the degree to which employees were aware that mechanisation impinged directly on their daily lives at work, is demonstrated by the multitude of articles and cartoons on the subject which appeared in the banks' staff magazines published between I 928 and I935. Three cartoons will suffice to illustrate the conscious perceptions of bank workers. First, Figure 5 illustrates not only the radical transformation of the work process, with hand-written ledgers replaced by machineprocessed records, but also aspects of gender associated with feminisation of the clerical 
labour force and the working environment.66 Although this picture undoubtedly overromanticises the lost gentlemanly attitude to female clerks, clearly the implications of women workers becoming extensions of a machine was evident to all bank workers. Second, issues of control and supervision of a branch bank are raised in Figure 6. Here representatives from headquarter offices, senior staff employed in the Inspection Department, appear as technicians arriving to scrutinise and fine-tune operation of a mechanical banking system at the local level. Finally, there were the customers. In addition to their own trepidations concerning change at work, bank workers were well aware of public anxiety concerning mechanisation. ${ }^{67}$ This apprehension was not confined to aspects of security nor to the accuracy of record-keeping. In Figure 7 an attempt to defraud a branch with a forged cheque has shocking consequences - but the cartoon also carries the implication that impersonal service threatened to damage the personal relationship which so many customers valued highly. As these cartoons so clearly illustrate, recognition of the cost cutting aspects of bank mechanisation alone would represent a failure to appreciate the far-reaching impact of this managerial and technical transformation.

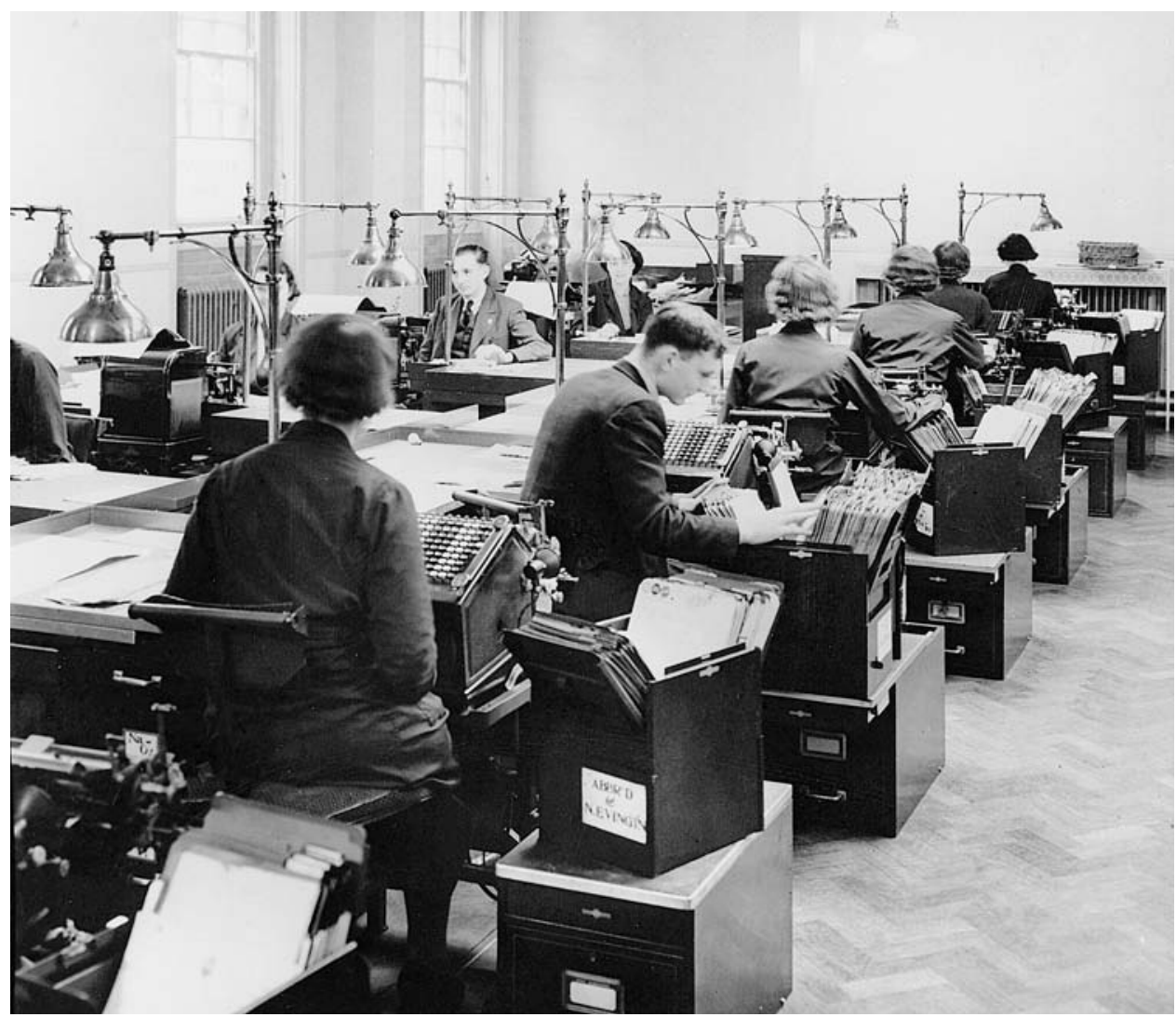

Figure 8. Mechanised banking at the Leicester Branch of the Westminster Bank, circa I938. (NatWest Group Archives) 


\section{Conclusions}

During the interwar period a managerial transformation of the 'Big Five' banks was achieved which belies their popular reputation as holders of conservative and traditionalistic attitudes. The solitary bank office or the small scale banking organisations which developed as the initial steps taken on the road to extensive branch banking were already regarded as quaint historic novelties by the Edwardian period. Banks as large business organisations with central offices overseeing numerous distant branches were already established before the First World War. While military service was an exogenous shock which altered temporarily the employment structure of the banks, some of whom admitted women as banking staff for the first time, 68 subsequent developments within the banks produced a discriminatory employment structure with selection by gender. The employment of women, at lower rates of remuneration, was not the only response of the banks to rising staff costs and machines were introduced in order to substitute capital for labour. However, the typical pattern was to jointly substitute female labour and accounting machines for male labour. Senior officers in the banks, having noted that female workers were adept in the use of keyboards and were employed in jobs which, by definition, excluded any promotion to managerial or executive positions, saw the potential offered by reorganization and mechanization to cut costs, standardize practices, impose supervision at all levels of activity, raise efficiency and, more generally, centralise the management of large scale, corporate organisations.

Although these developments have been documented in at least three of the more recent bank histories, ${ }^{69}$ the extent of this change has largely eluded economic historians of the interwar period who, for the most part, while noting the amalgamation movement, do not recognise the extent and significance of the associated changes in management structure and organisation. 70 Alford provides a very recent example of a literature which presents senior British bank officials as insular, amateurish, elitist, resistant to change and generally conservative:

'Yet there is evidence to suggest that merchant banks and other financial institutions

(including British multinational banks overseas) proved slow to adapt to changing conditions. Lack of entrepreneurial enterprise was no less evident in City banking parlours than it was in company boardrooms.' 71

In fact, professional management had replaced entrepreneurial enterprise in the 'Big Five' by the end of the r 920 .

In similar vein, the role of the banks in the alleged slow adoption of the corporate form in Britain provides the central thesis of Cottrell's recent essay, 'Finance and the germination of the British corporate economy'. This outlines the bank amalgamation movement and the development of national branch banking but, beyond mention of 'management styles' and 'the introduction of mechanised book-keeping',72 does not examine the emergence of corporate structures and the evolution of managerial organisation among the 'Big Five'. Rather, Cottrell opines that 'common to both large manufacturing companies and large commercial banks was the lack of managerial development, a corporate lag that was to persist until the 1960 s'.73 $^{\prime}$

This view is incompatible with the interwar managerial transformation of the 'Big Five'. Indeed, given the pace and extent of change between I928 and I934, similar 
changes in other business organisations might even warrant the description 'revolutionary' rather than 'evolutionary'. However, to affirm the extent of managerial changes within the 'Big Five' is not to suggest that all their managerial difficulties had been solved in the interwar period, nor that there was no potential for further development.

In addition, while it may be true of some elements of the manufacturing and extractive industries, for the banking sector, at least, there is also good reason to reject Alford's suggestion that the interwar years inherited a general reluctance to change the status quo post bellum which impeded the introduction of new techniques, methods and managerial structures:

'Central to the needs of business reorganization was technical change involving new labour practices and reduced manning levels. The war conspired to fuse the interests of businessmen and organized labour in their resistance to innovation.' 74

In the banking sector significant managerial and institutional changes began before the First World War, continued in novel directions during the War, and resulted in new organisational arrangements afterwards. In the case of commercial banking, at least: Britain was not slow to start down the path to corporate structures; Britain was not tentative in its adoption of these techniques; and, Britain did not lag significantly behind the USA, or Germany. Moreover, although British bankers were willing to learn from the practices and experiences of their contemporaries abroad, their implementation of this process was carefully considered, indigenously determined, and not imitative in nature.

Furthermore, this thesis can be gauged against Chandler's summary of the three pronged strategy adopted by managers of the modern industrial enterprise: 75 from 1900, if not before, the senior officials of British commercial banks: first, did invest in production facilities large enough to exploit the potential economies of scale or scope of the relevant technology; second, did invest in a national and international marketing and distribution network, so that the volume of sales might keep pace with the new volume of production; and, third, did invest in management so to benefit fully from the investment made in production facilities and the marketing and distribution networks. For a 'Big Five' British bank, the first two of these inter-related criteria were both achieved by investment in an extensive branch network controlled by a central head office; this strategy was also permissive of the adoption of new technology which not only cut costs but also increased the potential for managerial co-ordination and supervision. Here, investment in human capital, Chandler's third criterion, was essential. In English commercial banks managers were recruited and trained to ensure that they were able to administer the enlarged facilities and increased personnel required for production and distribution on a much enlarged scale; in addition, at the strategic level of senior management, systems were developed to monitor and co-ordinate those two basic functional activities and to plan and allocate resources for future production and distribution.

Perhaps Chandler's analytical framework can be made general; maybe its range stretches beyond the manufacturing sector. Here it is used to investigate the nature of investment to secure capabilities by the commercial banks, which are representative of the services sectors and, specifically, the financial services. Given the nature of Britain's economic development, it is not surprising that this development was well-established in the services sectors from a very early point in the history of this global phenomenon. However, this suggestion does not seem so far removed from Chandler's original conception which 
stressed the initial development and impact of managerial achievements in the service sectors: first, by the railroad, urban transit and telegraph companies and, second, by the urban departmental stores which took advantage of the distributive opportunities provided by the former. ${ }^{76}$ Yet another theme of Chandler's discussion of the emergence of the modern industrial corporation is the powerful competitive advantage achieved by a small number of first movers who quickly come to dominate their industry as oligopolists:77 given their size, longevity and the structure of their industry, the 'Big Five' British banks provide not only an excellent example of 'first mover advantage' but also a manifestation of the limitations of this concept. ${ }^{78}$

The developments in managerial structures and practices related here also have implications for any appraisal of the role of the 'Big Five' in the British economy. It would appear that much of the criticism voiced about the performance of the commercial banks in the interwar period has been misdirected. 79 In the I 920 , they were, of course, engaged collectively in industrial finance to an extent which was unprecedented. Moreover, it was because of this involvement that the commercial banks became so enmeshed in the rationalisation schemes which recently have been documented by various economic historians. 80 However, it is also clear that the commercial banks were themselves very much alive to the potential benefits of new management structures and new technology; specifically, they assessed and implemented the then progressive information technology offered by machine accounting.

In making their assessments of this machinery, the banks benefited from information relating not only to existing users of these capital goods, ranging from insurance firms to railway companies, both at home and abroad, but also from the manufacturers of office machinery themselves, who sought custom by providing advice about management information systems. 81 By 1930 senior managers of the 'Big Five' were well aware of the potentialities and pitfalls of technical change and the introduction of new management systems - from their own experiences. This alone must have confirmed to them that, although advice came cheap (and criticism even cheaper), what was really important was to know the organisation of an individual business inside out. Moreover, by the mid-I930s, with the diffusion of budgetary control and the development of more accurate costing systems, the major clearing banks could look forward to clients providing better quality information, confident that senior bank staff would be sufficiently experienced and better equipped to express an expert opinion on the technical excellence, credit worthiness and potential profitability of an applicant's business. 82 However, although the 'Big Five' had made the transition to the corporate form by the early i 930 , they could only encourage by example and exhortation, leading where many other firms would eventually follow.

In the four decades before I939 managerial structures of the 'Big Five' in Britain were transformed, albeit with different emphasises in each case and with responses which were determined by individual factors that had shaped the historical development of each bank's corporate culture. When we turn to the development of internal management structures, so essential for the elements which comprise the Corporate Economy, we find that British commercial banks had developed the structures which define competitive managerial capitalism. Furthermore, the managerial systems introduced before 1925 were the subject of subsequent systematic review. The introduction of new technology, in the form of machine accounting, was taken as an opportunity to assess not only the efficiency of the existing managerial systems but also to envisage alternatives - the banks engaged 
in a comprehensive review of their practices and systematically appraised options for the future.83 Recognition of this managerial dynamic calls into question not only the assumption, voiced not infrequently by economic historians of the interwar period, that the banks were conservative and ineffective, but also assertions of their naive disinterest in corporate development in the industrial sector.

The last word, like the first, perhaps should go to Keynes who demonstrated in 1927 a particularly percipient view of the future of banking organisation and mechanisation. In response to a question about the Labour Party's policy on nationalisation he reiterated his view that the 'Big Five' were already semi-socialised, or nationalised; in addition to their activities being of national scope, there was already a divorce between ownership and management and the banks were largely controlled by those in the receipt of salaries. Furthermore, indicating his appreciation of the extent, role and potential of the corporate organisation in the corporate economy, and anticipating correctly the reformist nature of twentieth century Labour governments, Keynes continued:

"The banks are evolving most of the things the Labour party wants everything to be like". What the Labour party wants is to make all other businesses like banks.' 84

\section{Acknowledgements}

My thanks to the Nuffield Foundation which financed this research [Research Grant $\mathrm{SOC} / \mathrm{I} 00$ (I 40I )] and to the archivists who offered their hospitality and advice concerning the records which record the history of the 'Big Five' British Banks: Jessie Campbell (Barclays Bank Group Archives); Edwin Green (HSBC Group Archives); Dr John Booker (Lloyds Bank Archives); and, Fiona McColl, Susan Snell and Derek Hammond (NatWest Group Archives). Professor Leslie Hannah provided much appreciated encouragement and assistance though he, like all mentioned here, is not responsible for the content. Dr Duncan Ross deserves a mention for 'leaning' on me to ensure that a version of this paper was scrutinised at the Monetary History Group Meeting in November I997; I also benefited from the constructively critical response of economic historians at the University of Leeds. A version of this paper was kindly presented on my behalf by Professor Michael Collins to the 'Banks as Firms' session of the I998 International Economic History Conference; Dr Trevor Boyns, Professor Geoffrey Channon and Professor Ranald Michie generously provided valuable suggestions incorporated here.

\section{Notes}

I. C. H. Lee, The British economy since I700: a macroeconomic perspective (Cambridge I986); Z. Griliches (ed.), Output measurement in the services sectors (Chicago I992); A. J. Field, 'The relative productivity of American distribution, I869-1992', Research in Economic History, vol. I6 (I996), pp. I-37.

2. N. Gemmell and P. Wardley, 'The contribution of services to British economic growth, I 856-1913', Explorations in Economic History, vol. 27 (I991), pp. 299-32 I.

3. C. H. Lee, 'Economic growth, structural change, labour productivity and industrialisation, I860-1913', research paper, University of Aberdeen (I986); C. H. Lee, 'Kaldor's laws and economic growth in historical perspective: the industrial economies I880-1973', research paper, University of Aberdeen (I987); S. N. Broadberry, 'Anglo-German productivity differences I870-I 990: a sectoral analysis', European Review of Economic History, vol. I ( 1997), 
pp. 247-267; S. N. Broadberry, 'Forging ahead, falling behind and catching-up: a sectoral analysis of Anglo-American productivity differences, I 870-1990', Research in Economic History, vol. i 7 (1997), pp. I-37.

4. P. Wardley, 'The anatomy of big business: aspects of corporate development in the twentieth century', Business History, vol. 33, no. 2 (I991), pp. 268-296.

5. R. Levine, 'Financial development and economic growth: views and agenda', Journal of Economic Literature, vol. XXXV (I997), p. 688.

6. Walter Bagehot, Joseph Schumpeter, John Hicks, Alexander Gerschenkron and Raymond Goldsmith appear as Levine's proponents of the importance of the financial system and its institutions; the dissenters, a smaller brethren, include Robert Lucas, Anand Chandavarkar and Joan Robinson; Levine, 'Financial development', p. 688.

7. M. Collins, 'English bank development within a European context', Economic History Review, vol. LI, no. I ( I 998), pp. I-24

8. A. D. Chandler, Jnr., Strategy and Structure: chapters in the history of industrial enterprise (Cambridge, Mass 1962); A. D. Chandler, Jnr., The Visible Hand: the managerial revolution in American business (Cambridge, Mass. I 977); L. Hannah, The rise of the corporate economy (London 1973).

9. P. L. Payne, The emergence of the large scale company in Great Britain, I870-I9I4', Economic History Review, vol. 20 ( 1967 ), pp. 519-542.

ı. A. D. Chandler, Jnr., Scale and Scope: the dynamics of industrial capitalism (Cambridge, Mass., I990), p. I2.

I I. Chandler, Scale and Scope, p. 8.

I2. L. Hannah, 'Scale and Scope: towards a European Visible Hand?', Business History, vol. 33, no. 2 ( I991), pp. 297-309; B. Supple, 'Scale and Scope: Alfred Chandler and the dynamics of industrial capitalism', Economic History Review, vol. xliv, no. 3 (I99I), pp. 500-5I 4.

13. A different view of industrial development in the United States which stresses speciality production and regional networks is provided by P.Scranton, Endless Novelty: Speciality Production and American Industrialization (Princeton, N. J., I997).

I4. Y. Cassis Big Business: the European experience in the twentieth century (Oxford I997).

I 5. For example, W. Lazonick, Business organization and the myth of the market economy (New York I 99I), p. 48-49.

I6. P. Wardley, 'The anatomy of big business: aspects of corporate development in the twentieth century', Business History, vol. 33, no. 2 (I99I), pp. 268-296; C. Schmitz, The growth of big business in the United States and Western Europe, 1850-1939 (London 1993); L. Hannah, 'Symposium on "The American Miracle": Afterthoughts', Business and Economic History, vol. 24, no. 2 (I995), pp. 246-262; P. Wardley, 'The emergence of Big Business: the largest corporate employers of labour in the United Kingdom, Germany and the United States c. I907.' Business History, vol. 4I, no. 4 (I999), pp. 88-i r6.

I 7. Wardley, 'Anatomy', p. 288. One of the indicators most favoured by proponents of the thesis of British entrepreneurial failure in this period, the inability of British businessmen to develop large corporations, thereby fails this most obvious test.

18. M. Collins, Banks and industrial finance in Britain 1800-1939 (London 1991); F. Capie and M. Collins, 'Deficient suppliers? Commercial banks in the United Kingdom, I870-1980' and D. M. Ross, 'The 'Macmillan gap' and the British credit market in the I930s': both in P. L. Cottrell, A. Teichova and T. Yuzawa (eds.), Finance in the age of the corporate economy (Aldershot 1997), pp. I64-183, pp. 209-226.

I9. M. Best and J. Humphries, 'The City and industrial decline' in B. Elbaum and W. Lazonick (eds.), The decline of the British economy (London i986), pp. 223-239; S. Tolliday, Business, Banking and Politics: the case of British steel, 1918-1936 (Cambridge 1987).

20. D. Ross, 'Information, collateral and British bank lending in the I93os' in Y. Cassis, G. Feldman, and U. Olsson (eds.), The evolution of financial institutions and market in twentieth century Europe (Aldershot 1995), pp. 273-294.

2 I. (Macmillan) Committee on Finance $\mathcal{E}$ Industry Report (London I93 I), especially pp. I02-105, I6I-I 73 and the dissenting views attached to the Report, pp. I90-28I. 
22. The first three indicators listed here receive fuller attention here, though data for the other three are readily available (for example, deposits and advances were recorded in monthly returns of the London clearing banks and reported profits were published in the balance sheets).

23. A. R. Holmes and E. Green, Midland: 150 years of banking business (London I986), pp. 332-335, provides actual profits for the Midland Bank; comparative data for Barclays Bank have been estimated by Leslie Hannah (forthcoming).

24. See also M. Collins, 'The growth of the firm in the domestic banking sector', in M. W. Kirby and M. B. Rose (eds.), Business enterprise in modern Britain: from the eighteenth to the twentieth century (London 1994), pp. 278-286.

25. F. Capie, 'Structure and Performance in British Banking, I870-1939', in P. L. Cottrell and D. E. Moggridge, Money and Power: essays in honour of L. S. Pressnell (London 1988), pp. 73I02; P. L. Cottrell, 'Finance and the germination of the British corporate economy', and C. Munn, 'Banking on branches: the origins and development of branch banking in the United Kingdom'; both in Cottrell, Teichova, and Yuzawa, Finance, pp. 5-36 and 37-5I respectively.

26. F. Capie and G. Rodrik-Bali, 'Concentration in British Banking I880-1920', Business History, 24 (I982), pp. 280-292.

27. For contemporaries the term 'rationalisation' was often loosely applied to any kind of managerial change, including: amalgamation; merger; reorganisation; the adoption of new technology, often American in origin; measures taken to increase concentration or even reduce the range of product lines. In the case of the 'Big Five' rationalisation does appear to have been pursued in the narrower, economic sense: that is, the managed redeployment of capital and labour to achieve optimal, or near optimal, output and productivity after a rational assessment of the market and available factors of production. For example, between 1920 and I 929 the Midland Bank established 638 new branches but also closed 9i branches to curtail duplication of local banking provision following amalgamations with the Metropolitan Bank ( I914) and the London Joint Stock Bank (1918), Holmes and Green, Midland, pp. I27, I3 I, r69-I 70; see also J. R. Winton, Lloyds Bank 1918-1969 (London, I982) p. 70. Evidence of 'Rationalisation' has been suggested as a test of Chandler's assertion that the conventional ideas associated with personal capitalism dominated in interwar Britain by J. Wilson, British business history, I720-1994 (London 1995) p. I 44.

28. Holmes and Green, Midland, p. I 75; Winton, Lloyds Bank 1918-1969, p. 5 I.

29. At the beginning of the interwar period it was commonly held to be the largest bank in the world.

30. A. W. Tuke and R. J. H. Gillman, Barclays Bank Limited I926-1969: some recollections (London 1972), p. 21-23; Holmes and Green, Midland, pp. I67, I96.

31. Tuke and Gillman, Barclays Bank Limited I926-1969, pp. 20-23; F. Carnevali,'Finance in the regions: the case of England after I945' in Cassis, Feldman, and Olsson (eds.), The evolution of financial institutions, pp. 295-3 r4.

32. W. F. Crick and J. E. Wadsworth, A hundred years of joint stock banking (London I958), p. 34I.

33. Crick and Wadsworth, A hundred years, p. 340-34I.

34. For example, see Holmes and Green, Midland: p. I Iо, figure 4.I, 'The Midland board and management structure, c. I900'; and, p. I9I, figure 7.I, 'Midland Bank board and management structure, c. 1929'.

35. L. le M. Minty, English banking methods (London 1930).

36. Minty, English banking methods, p. I27-129.

37. By the author.

38. Winton, Lloyds Bank, p. 34 .

39. Holmes and Green, Midland, p. I32.

40. Tuke and Gillman, Barclays Bank Limited, p. 8I.

4I. Like Figure I, Figure 2 is a "model" or archetype and derives from Minty, English Banking

Methods, pp. I 29, 445-532.

42. Minty, English banking methods, p. 127-129.

43. Minty, English banking methods, pp. I 29-140. 
44. The origins, nature and development of The Bible, the alphabetical listing employees of Lloyds Bank, are described in K. Stovel, M. Savage and P. Bearman, 'Ascription into achievement: models of career systems at Lloyds Bank, I890-1970', American Journal of Sociology, vol. I02, no 2 (1996), pp. 366-376.

45. P. B. Doeringer and M. J. Piore, Internal labour markets and manpower analysis (Lexington, Mass. I97I).

46. Bank managers were one of a few high status groups who could vouch for an individual applying for a British passport.

47. Women also experienced other forms of discrimination relating to remuneration: those re-employed in the 1920 often received no recognition of their previous employment and admission of women to the banks' contributory pension schemes was delayed. At Lloyds Bank, for example, the contributory pension scheme was introduced for men in 1930 and for women in 1936; Winton, Lloyds Bank, p. 74.

48. Women staff were expected to be single and to resign on marriage; this was not solely a gender issue as junior male staff were strongly encouraged to remain bachelors in the early years of their career.

49. O. E. Williamson, M. L. Wachter and J.E. Harris, 'Understanding the employment relation: the analysis of idiosyncratic exchange', Bell Journal of Economics and Management Science, 6 (1975), pp. 250-278.

50. J. T. Addison and W. S. Siebert, The market for labor: an analytical treatment (Santa Monica, California I979), p. I 88.

5I. Office technology and its early twentieth century usage is extensively illustrated and described in D. Gardey, 'Pour une histoire technique du métier de comptable: évolution des conditions practiques du travail de comptabilité du début du XIX ${ }^{\mathrm{e}}$ siècle à la veille de la Seconde guerre mondiale', Troisiemes journées d'Histoire de la Comptabilité: Hommes, saviors et practiques de la Comptabilité (Nantes, 1997), pp. 3-36.

52. S. J. Gould, 'Cordelia's dilemma', Dinosaur in a haystack (London 1996), pp I23-132.

53. H. C. F Holgate, 'The scope for further mechanization', The Banker, vol. xliii ( I938), pp. 56-57.

54. Anon., 'Mechanical accounting', The Banker, vol. xi (ig29) pp. i64-i65.

55. H. L. Rouse, 'The progress of mechanization' The Banker, vol. xvi (I930), p. I25.

56. H. L. Rouse, 'A general review of six years of mechanization', The Banker, vol. xxvii (1933), p. 238.

57. The adoption of this term by the Midland Bank may have had unanticipated consequences in the historical analysis of twentieth century British banking: the use of 'centralisation' to describe grouping by branch for information processing purposes seems to have contributed to the perception that the Midland Bank was more 'centralised' than its rivals.

58. Minty, English banking methods, pp. 192-195.

59. Rouse, 'The progress of mechanization', pp. I22-1 26.

6o. A. C. Parker, 'Machine accountancy at Westminster Bank, Lothbury', The Banker, vol. xxvii (July i933), p.6r.

6r. Parker, 'Machine accountancy', pp. 64-65.

62. Parker, 'Machine accountancy', p. 66.

63. Parker, 'Machine accountancy', p. 60.

64. Rouse, 'A general review', p. 244 .

65. This is an estimate of annual salary savings, minus machine costs, including depreciation, at the 'Big Five' Banks in I939. Based on information contained in contemporary sources, including articles cited here and numerous internal reports concerning mechanization, it is a smaller saving than that suggested either by ex ante predictions or by savings reported by the staff closely associated with mechanisation. Further details will be provided in a forthcoming analysis of output, employment and productivity in the British banking industry.

66. For the United States, an extensive discussion of gender, the development of clerical occupations and the construction of work in commercial offices is provided by A. Kwolek-Folland, Engendering Business: Men and Women in the Corporate Office, I870-1930 (Baltimore 1995). 
67. 'A Banker', 'Bank Mechanization as affecting Personnel and Public', The Banker, vol. xliii ( I938) pp. 6o-6r.

68. E. R. Long, 'The future position of women clerks in banks', Journal of the Institute of Banking, vol. XLIV (I923), pp. I I 4-23.

69. Holmes and Green, Midland, pp. I 7 I-I 74, I90-193; Tuke and Gillman, Barclays, pp. 93-94; and, Winton, Lloyds Bank, p. 84-9I.

70. For example, S. Pollard, The development of the British economy I9I4-1980 (3rd edn, London, I983), p. I47: 'The joint-stock banks had, by the early i93os, fully completed the process of amalgamation that was all but consummated by $1920 . '$

71. B. W. E. Alford, Britain in the World Economy since I880 (London 1996), p. I2 I.

72. P. L. Cottrell, 'Finance and the germination of the British corporate economy', p. 26.

73. As further evidence of corporate lag, Cottrell also suggests that few direct communications existed between the large banks and the large manufacturing firms, Cottrell, 'Finance', p. 3 I. However, by the I930s a dense and complex network of inter-locking directorates had developed to link the boards of Britain's largest companies which encompassed the Big Five Banks: P. Wardley, 'Aspects of Corporate Development in the Twentieth Century: the Anatomy of Britain's Largest Fifty Companies in 1904, I934 and 1985 by Absolute Size, Relative Size, Concentration, Geographical Location and Inter-Locking Directorates', UWE Research Paper in Business History, no. I (I990); also see the author's 'Big Business' webpages at the University of the West of England's website: www. uwe. ac. uk.

74. Alford, Britain, p. I26.

75. Chandler, Scale and Scope, p. 8; cited at p. 73 above.

76. Chandler, Strategy and Structure, p. 232: Field, 'The relative productivity', p. I8-ig.

77. Chandler, Scale and Scope, p. 8

78. The Midland Bank survived until 1992, when it was acquired by the Hong Kong and Shanghai Bank to form HSBC Holdings plc. The National Westminster Bank, created by the merger of the Provincial Bank and the Westminster Bank in I970, survived until 2000 when, as the NatWest Group, it was acquired by the Royal Bank of Scotland. At the beginning of the twenty first century, therefore, only two of the 'Big Five' survived as independent banking corporations: Barclays Bank and Lloyds Bank.

79. F. Capie and M. Collins 'Deficient suppliers?' pp. I69-г 76.

8o. S. Tolliday, Business, Banking and Politics, p. I 77; M. Kirby, 'The Lancashire cotton industry in the interwar years: a study in organisational change', Business History, vol. I6. (I974) pp. I44-I 59 .

8I. An excellent example of this interaction is provided by JoAnne Yates, 'Co-evolution of Information-processing technology and use: interaction between Life Insurance and Tabulating industries, Business History Review vol. 67 (Spring I993), pp. I-5 I.

82. C. R. Curtis, 'Office rationalisation and the banks', The Banker, vol. xxxv (July 1935), pp. 49-54.

83. Recent research has provided similar examples of management reorganisation introduced to achieve administrative and financial control during the interwar period. For example, L. Cailluet, 'Accounting and accountants as essential elements in the development of central administration during the interwar period: management ideology and technology at Alais, Froges et Camargue (AFC-Pechiney)', Accounting, Business and Financial History, vol. 7, no. 3 (I997), pp. 295-314 provides an excellent example of a large French industrial corporation which transformed its managerial structures and procedures, incorporating office machinery worked largely by females, to cope with the challenges of increased scale, scope and geographic diversification.

84. Anon., 'Mr J.M. Keynes on banking services', Journal of the Institute of Banking, vol. xlviii (November 1927), p. 497 . 